\title{
THE INTERACTION OF POLYACID-MODIFIED COMPOSITE RESINS (“COMPOMERS”) WITH AQUEOUS FLUORIDE SOLUTIONS
}

\author{
Reza ROHANI ${ }^{1}$, John W. NICHOLSON ${ }^{2}$
}

1- School of Science, University of Greenwich, Chatham, United Kingdom.

2- PhD, BSc, School of Science, University of Greenwich, Chatham, United Kingdom.

Corresponding address: John W. Nicholson - School of Science - University of Greenwich - Medway Campus - Chatham - Kent ME4 4TB - United Kingdom - e-mail: J.W.Nicholson@greenwich.ac.uk

Received: September 24, 2008 - Accepted: November 10, 2008

\begin{abstract}
Q

bjective: The aim of this study was to investigate how the release of fluoride from two compomers and a fluoridated composite resin was affected by exposure to KF solution. Material and Methods: Two compomers (Dyract AP and Compoglass F) and one fluoridated composite (Wave) were prepared as discs ( $6 \mathrm{~mm}$ diameter and $2 \mathrm{~mm}$ thick), curing with a standard dental lamp. They were then stored in either water or $0.5 \% \mathrm{KF}$ for 1 week, followed by placement in water for periods of 1 week up to 5 weeks total. Fluoride was determined with and without TISAB (to allow complexed and decomplexed fluoride to be determined), and other ion release ( $\mathrm{Na}, \mathrm{Ca}, \mathrm{Al}, \mathrm{Si}, \mathrm{P})$ was determined by ICP-OES. Results: Specimens were found not to take up fluoride from $100 \mathrm{ppm} \mathrm{KF}$ solution in $24 \mathrm{~h}$, but to release additional fluoride when stored for up to five weeks. Compomers released more fluoride cumulatively following exposure to KF solution $(\mathrm{p}<0.001)$, all of which was decomplexed, though initial ( 1 week) values were not statistically significant for Dyract AP. Other ions showed no variations in release over 1 week, regardless of whether the specimens were exposed to KF. Unlike the compomers, Wave showed no change in fluoride release as a result of exposure to KF. Conclusions: Compomers are affected by KF solution, and release more fluoride (but not other ions) after exposure than if stored in water.
\end{abstract}

Key words: Composite resins. Fluoride.

\section{INTRODUCTION}

Compomers (polyacid-modified composite resins) are esthetic materials chemically similar to the well-established composite resins ${ }^{8}$. They were introduced to the dental profession in the early $1990 \mathrm{~s}^{10}$, and were intended to combine the benefits of traditional composite resins and those of glass-ionomer cements ${ }^{16}$. These materials are now considered a distinct class of dental restorative, with well-established uses in clinical restoration, particularly in children's dentistry ${ }^{13}$.

Compomers set by an addition polymerization reaction, typically light initiated due to the action of blue light $(470 \mathrm{~nm}$ wavelength) on camphorquinone with amine accelerator ${ }^{13}$. One brand, designed for use as a luting cement, is a two-paste system $^{14}$, and cure is brought about by mixing the two pastes, each of which contains a component of the free radical initiator system.

Compomers do not contain water, but are formulated from similar components to conventional composite resins, namely macromonomers, such as bis-glycidyl ether dimethacrylate (bisGMA) and/or urethane dimethacrylate, blended with viscosity-reducing diluents, such as triethylene glycol dimethacrylate (TEGDMA). These polymer systems are filled with non-reactive inorganic powders, for example quartz or a silicate glass ${ }^{4}$.

Compomers contain extra monomers that contain acidic functional groups. The most widely used monomer of this type is so-called TCB, which is a di-ester of 2-hydroxyethyl methacrylate with butane tetracarboxylic acid ${ }^{4}$. This acidfunctional monomer is very minor component and compomers also contain some reactive glass powder of the type used in glass-ionomer cements ${ }^{8}$. Despite the presence of these additional components, compomers set by a polymerization reaction. It is only once they are set that they draw in a small amount of water to promote a secondary neutralization reaction ${ }^{4}$. They lack the ability to bond to tooth tissues ${ }^{1,9,11}$, so require the use of bonding agents ${ }^{1,12}$ and their fluoride release levels are lower than those of glass-ionomer cements ${ }^{6,18}$.

Fluoride in compomers is present in the reactive glass filler, and becomes available for release following reaction of this glass with the acid functional groups, triggered by moisture uptake. Commercial compomers also contain fluoride compounds such as strontium fluoride or ytterbium fluoride, and these are capable of releasing free fluoride ion under clinical 
conditions. Fluoride release is enhanced in acidic conditions ${ }^{17,21}$, and in lactate buffer has been shown to be diffusion-based ${ }^{17}$.

Conventional composite resins can also be formulated to allow them to release fluoride ${ }^{5}$. Unlike glass-ionomers or compomers, composite resins are not inherently fluoridereleasing, but the addition of compounds such as $\mathrm{NaF}, \mathrm{YbF}_{3}$ or ion-leachable glass, can make them release clinically useful amounts of fluoride 7 . Organic fluorides can be used, too, such as methacryloyl fluoride-methyl methacrylate (MF-MMA) or tetrabutyl ammonium tetrafluroborate. These substances impart the property of slow release of fluoride to the surrounding tissue without the creation of voids within the material ${ }^{7}$.

Fluoride release from composite resins differs from that in glass-ionomers (conventional or resin-modified) in two important respects. First, it tends to be a gradual, sustained process throughout the lifetime of the restoration ${ }^{5,7}$, and lacks the initial burst immediately after placement that characterises glass-ionomers. Second, these materials are reported to be unable to undergo fluoride recharge ${ }^{19}$. This inferred from the lack of additional fluoride release following storage in fluoride solutions, and has not been measured directly ${ }^{20}$.

Reported results for fluoride-uptake by compomers are ambiguous. According to Attin, et al. ${ }^{2}$ compomers released no more fluoride in 1 week after exposure to aqueous potassium fluoride solution than those conditioned in water. On the other hand, according to Preston, et al. ${ }^{15}$, compomers do release more fluoride after such treatment. This led to opposing conclusions about the possibility of fluoride being taken up and re-released by compomers ${ }^{14,15}$. The present work has been undertaken in an attempt to resolve this contradiction. In particular, the hypothesis tested is that compomers take up fluoride from aqueous solution, and having done so, release additional fluoride compared with a control groups stored in pure water. The effect of fluoride on the release of other ions ( $\mathrm{Al}, \mathrm{Ca}, \mathrm{Na}, \mathrm{Si}, \mathrm{P})$ has also been determined.

\section{MATERIAL AND METHODS}

Two restorative-grade compomers were used (Dyract AP; Dentsply DeTrey, Konstanz, Germany and Compoglass F; Ivoclar Vivadent, Schaan, Liechtenstein). Disc-shaped specimens ( $6 \mathrm{~mm}$ diameter $\mathrm{x} 2 \mathrm{~mm}$ height) were prepared using silicone rubber moulds with glass microscope slides to cover each face. Samples were cured by irradiation with a conventional dental curing light fitted with a halogen bulb designed to emit blue light at $470 \mathrm{~nm}$ wavelengths. Specimens were cured for $40 \mathrm{~s}$ each side, a procedure based on the manufacturers' recommendations of curing each layer for a minimum of $40 \mathrm{~s}$. Cured specimens were stored in solution in plastic sample tubes to avoid ionic contamination from glass vessels.

The possibility of fluoride uptake was studied by preparing a set of three specimens of each material, and storing them in individual $2 \mathrm{~cm}^{3}$ volumes of $100 \mathrm{ppm} \mathrm{F}^{-}$(as KF) solution at room temperature $\left(21-23^{\circ} \mathrm{C}\right)$ for $24 \mathrm{~h}$. After this time, fluoride concentration was measured using a fluoride-selective electrode (type PSE) that had been calibrated immediately before use.
The $\mathrm{pH}$ of these solutions was checked by measuring with a freshly calibrated $\mathrm{pH}$ meter (PHP-100-020M, Whatman, UK).

For the study of effect of conditioning, sets of six specimens of each material were prepared and stored ("conditioned") at room temperature $\left(21-23^{\circ} \mathrm{C}\right)$ in $5 \mathrm{~cm}^{3}$ volumes of aqueous solution (demonized water or $0.5 \% \mathrm{KF}$ solution) and agitated from time to time. After 1 week, they were removed and dried by blotting with tissues. Each set of specimens were then placed in individual $5 \mathrm{~cm}^{3}$ volumes of water (ie $5 \mathrm{~cm}^{3}$ per specimen) and stored for a further periods of a week up to 5 weeks at room temperature. At the end of each week, they were removed, dried and transferred to a fresh volume of water.

Storage solutions were analysed for their $\mathrm{Na}, \mathrm{Ca}, \mathrm{Al}, \mathrm{P}$ and Si content after one week, using inductively coupled plasma with optical emission spectroscopy (ICP-OES). The ICP spectrometer was calibrated before use, with standard solutions of the specific ions to be determined, and with $\mathrm{R}^{2}$ values of at least 0.999 .

Fluoride ion concentration was also determined each week on these solutions using a fluoride-selective electrode (type PSE) calibrated immediately before use. Fluoride levels were determined with and without the addition of an equal volume of total ionic strength adjustment Buffer(TISAB) decomplexing agent, calibrations having previously been made with TISAB present. This enabled both free and complexed fluoride to be determined.

Statistical significance of differences in data was determined using Student's t-test.

\section{RESULTS}

The fluoride solution was found to have a $\mathrm{pH}$ close to neutral (6.6), which was the same as that of the water used for the storage and release experiments. Neither material showed any evidence of fluoride uptake when fluoride concentration was measured directly in KF solution in which specimens had been placed for $24 \mathrm{~h}$. After $24 \mathrm{~h}$, the fluoride meter reading still corresponded to $100 \mathrm{ppm}$.

Both materials released fluoride when stored in pure water, as shown in Table 1. Total fluoride was found to be the same (with statistical limits) as free fluoride in all cases, showing that all $\mathrm{F}^{-}$is released as the free ion, not as part of a complex. Both brands of compomer showed an increase in fluoride release after initial storage in KF solution for 1 week compared with specimens stored in pure water $(\mathrm{p}<0.001)$.

For Dyract AP, week 1 release was higher by a statistically significant amount $(p<0.01)$ than all others. Also, the cumulative release over the 5 weeks showed significantly greater fluoride release after initial storage in KF solution $(p<0.001)$. Despite this, after week 1 , the difference in fluoride release when conditioned in KF was not significant. However, it was significant $(p<0.05)$ in week 2 . These results thus show evidence of enhanced $\mathrm{F}^{-}$release as a result of early exposure to $\mathrm{KF}$ solution.

For Compoglass $\mathrm{F}$, the release of fluoride after storage in water in week 1 was also significantly higher than all others $(p<0.01)$, and Compoglass $F$ had higher cumulative release of 
TABLE 1- Fluoride release values (ppm in $5 \mathrm{~mL}$, standard deviations in parentheses)

\begin{tabular}{|c|c|c|c|c|c|c|}
\hline Material & Week 1 & Week 2 & Week 3 & Week 4 & Week 5 & $\begin{array}{c}\text { Cumulative } \\
\text { release }\end{array}$ \\
\hline \multicolumn{7}{|c|}{ Dyract AP } \\
\hline \multicolumn{7}{|l|}{ Water } \\
\hline $\mathrm{F}$ & $4.5(1.4)^{a}$ & $0.9(0.2)^{b}$ & $1.1(0.3)^{b}$ & $1.1(0.2)^{b}$ & $0.4(0.1)^{c}$ & $8.0(1.5)^{d}$ \\
\hline $\mathrm{T}$ & $3.2(1.6)^{\mathrm{a}}$ & $1.0(0.4)^{b}$ & $1.0(0.3)^{\mathrm{b}}$ & $1.1(0.2)^{\mathrm{b}}$ & $0.6(0.1)^{c}$ & $6.9(1.6)^{d}$ \\
\hline \multicolumn{7}{|l|}{ KF } \\
\hline $\mathrm{F}$ & $6.6(4.3)^{\mathrm{e}}$ & $1.9(0.1)^{f}$ & $1.4(0.5)^{\mathrm{g}}$ & $0.9(0.1)^{b}$ & $0.6(0.2)^{c}$ & $11.4(4.4)^{\mathrm{h}}$ \\
\hline $\mathrm{T}$ & $6.4(4.8)^{\mathrm{e}}$ & $2.1(0.2)^{\dagger}$ & $1.0(0.3)^{\mathrm{g}}$ & $1.0(0.1)^{b}$ & $0.8(0.3)^{c}$ & $11.3(4.6)^{\mathrm{h}}$ \\
\hline \multicolumn{7}{|c|}{ Compoglass } \\
\hline \multicolumn{7}{|l|}{ Water } \\
\hline $\mathrm{F}$ & $3.9(1.3)^{i}$ & $3.1(0.6)^{i}$ & $2.5(0.8)^{i}$ & $3.5(0.4)^{i}$ & $2.2(0.4)^{i}$ & $15.2(1.5)^{\mathrm{k}}$ \\
\hline $\mathrm{T}$ & $8.0(3.4)^{i}$ & $3.4(0.6)^{i}$ & $2.5(0.6)^{i}$ & $3.7(0.2)^{i}$ & $2.3(0.6)^{i}$ & $19.9(3.6)^{\mathrm{k}}$ \\
\hline \multicolumn{7}{|l|}{ KF } \\
\hline $\mathrm{F}$ & $13.2(2.5)^{1}$ & $6.6(1.2)^{\mathrm{m}}$ & $3.9(1.2)^{n}$ & $4.6(1.2)^{n}$ & $2.7(0.8)^{i}$ & $31.0(2.6)^{\circ}$ \\
\hline $\mathrm{T}$ & $16.4(3.3)^{\prime}$ & $8.1(1.9)^{\mathrm{m}}$ & $3.9(1.0)^{n}$ & $5.0(1.3)^{n}$ & $2.7(0.8)^{i}$ & $36.1(3.4)^{\circ}$ \\
\hline
\end{tabular}

Different letters mean statistically significant difference

TABLE 2- Ion release after one week as determined by ICP-OES (ppm in $5 \mathrm{~mL}$, standard deviations in parentheses)

\begin{tabular}{lccc}
\hline Material & Element & Conditioned in water & Conditioned in KF solution \\
\hline Dyract AP & $\mathrm{Al}$ & $0.4(0.1)$ & $0.4(0.1)$ \\
& $\mathrm{Ca}$ & $2.9(1.6)$ & $1.5(1.2)$ \\
$\mathrm{Na}$ & $5.8(1.7)$ & $10.4(8.7)$ \\
$\mathrm{Si}$ & $1.0(0.4)$ & $0.9(0.3)$ \\
$\mathrm{P}$ & $0.8(0.6)$ & $1.7(0.8)$ \\
Compoglass F & & $0.5(0.3)$ & $0.5(0.2)$ \\
& $\mathrm{Al}$ & $4.5(1.2)$ & $4.4(1.8)$ \\
$\mathrm{Ca}$ & $2.6(0.7)$ & $4.7(2.2)$ \\
$\mathrm{Na}$ & $3.0(1.9)$ & $1.2(0.4)$ \\
& $\mathrm{Si}$ & $0.6(0.4)$ & $0.7(0.7)$
\end{tabular}

fluoride over five weeks than Dyract AP.

Storage of Compoglass $\mathrm{F}$ in $\mathrm{KF}$ solution caused higher $\mathrm{F}^{-}$ release in week 1,2 and $3(\mathrm{p}<0.01)$ compared with storage in water. Fluoride release was also higher in weeks 4 and 5, but not to a significant extent. Overall, the cumulative fluoride release was higher $(\mathrm{p}<0.001)$ from specimens exposed to KF. These results show that Compoglass $\mathrm{F}$ is more influenced by exposure to KF solutions than Dyract AP.

Results for ICP-OES after one week are shown in Table 2. The important results to compare are for individual materials stored initially in either water or KF solution and it will be seen from Table 2 that there are no significant differences for any of the elements released. This shows that the initial storage solution has no effect on the overall pattern of ion release. This is different from glass-ionomer cements, which showed a statistically significant rise in release of all ions when they had been exposed to potassium fluoride solution ${ }^{7}$, and was evidence of the apparent etching effect of neutral aqueous potassium fluoride.

\section{DISCUSSION}

The compomers were found to exhibit somewhat paradoxical behavior. They appeared to take up no fluoride when stored in KF solution, at least within the limits of detection of the ion-selective electrode used. However, despite this apparent lack of uptake, both compomers released more fluoride following exposure to KF solution. This was statistically significant $(\mathrm{p}<0.001)$ in terms of cumulative release over 5 weeks, even though it was not always significant on a week by week basis.

This might suggest that the additional fluoride release arises 
due to an effect similar to that which occurs with glass ionomers ${ }^{3}$, where the surface is roughened and appears visibly etched, even though the $\mathrm{KF}$ is approximately neutral in $\mathrm{pH}^{3}$. However, this interpretation is not supported by the ICP-OES results for ion-release, after 1 week. None of the other ions showed any significant increase as a result of storage in KF solution, yet an "etching" effect would be expected to affect all of the ionic components, and lead to increased release of these ions. Despite this result, something akin to this effect seems the best explanation for the results obtained for compomers.

Previous reports have been contradictory about whether compomers are influenced by exposure to fluoride in solution ${ }^{14,15}$. The results of the present study show that the effect varies with the material's brand, and with the experiment duration. The previous study ${ }^{14}$ that reported no effect of exposing compomers to fluoride solution seems to have used a relatively insensitive brand, and reported experiments carried out over a too short period (only 1 week). In the present investigation, one compomer brand, Dyract AP, did not have a significant effect until week 2. Overall, the results demonstrate that, over a longer period, and considering cumulative release, compomers are able to release additional fluoride after exposure to fluoride solution. These results are consistent with those of Preston, et al. ${ }^{15}$.

\section{CONCLUSIONS}

This study showed that compomers do not take up measurable amounts of fluoride from solution. Despite this, release of fluoride from compomers is increased by early exposure to KF solution. This suggests that KF solution causes fluoride already present in the compomer to be released in increased amounts, though the mechanism by which this behavior occurs is not clear. Other ions ( $\mathrm{Na}, \mathrm{Ca}, \mathrm{Al}, \mathrm{P}$ and $\mathrm{Si}$ ) did not show such increase. Compoglass $F$ was affected much more than Dyract AP, and showed a much greater increase in fluoride release. From this it is concluded that the effect varies with different compomer formulations. Further research is necessary to fully understand the mechanism of fluoride release by compomers, and also to determine how exposure to external fluoride solutions influences this process.

\section{ACKNOWLEDGMENT}

We would like to thank Miss Samantha Booth for carrying out the ICP-OES analyses.

\section{REFERENCES}

1- Arends J, Ruben J, Dijkman AG. The effect of fluoride release from a fluoride-containing composite resin on secondary caries: an in vitro study. Quintessence Int. 1990;21(8):671-4.

2- Attin T, Buchalla W, Siewert C, Hellwig E. Fluoride release/uptake of polyacid-modified resin composites (compomers) in neutral and acidic buffer solutions. J Oral Rehabil. 1999;26(5):388-93.
3- Billington RW, Williams JA, Pearson GJ. Glass ionomer as a rechargeable reservoir for physiologically active ions. In: Transactions of the Fourth World Biomaterials Congress. Berlin: European Society for Biomaterials; 1992. p. 213.

4- Eliades G, Kakaboura A, Palaghias G. Acid base reaction and fluoride release profiles in visible light-cured polyacid modified composite resin restorations. Dent Mater. 1998;14(1):57-63.

5- Eichmiller FC, Marjenhoff WA. Fluoride-releasing dental resorative materials. Oper Dent. 1998;23(5):213-8.

6- Grobler SR, Rossouw RJ, Van Wyk K. A comparison of fluoride release from various dental materials. J Dent. 1998;26(3):256-65.

7- Karantakis P, Helvatijoglou-Antoniades M, Theodoridou-Pahini S, Papadogiannis Y. Fluoride release from three glass ionomers, a compomer, and a composite resin in water, artificial saliva, and lactic acid. Oper Dent. 2000;25(1):20-5.

8- McLean JW, Nicholson JW, Wilson AD. Proposed nomenclature for glass ionomer dental cements and related materials. Quintessence Int. 1994;25(9):587-9.

9- Martin R, Paul SJ, Luthy H, Scharer P. Dentin bond strength of Dyract Cem. Am J Dent. 1997;10(1):27-31.

10- Meyer JM, Cattani-Lorente MA, Dupuis V. Compomers: between glass ionomer cements and composites. Biomaterials. 1998;19(6):529-39.

11- Millar BJ, Abiden F, Nicholson JW. In vitro caries inhibition by polyacidmodified composite resins (“compomers"). J Dent. 1998;26(2):133-6.

12- Moodley D, Grobler SR. Compomers: adhesion and setting reactions. S Afr Dent J. 2003;58(1):24-8.

13- Nicholson JW. Polyacid modified composite resins ("compomers") and their use in clinical dentistry. Dent Mater. 2006;23(5):615-22.

14- Nicholson JW, McKenzie MA. The properties of polymerisable luting cements. J Oral Rehabil. 1999;26(10):767-74.

15- Preston AJ, Higham SM, Agalamanyi EA, Mair LH. Fluoride recharge of aesthetic dental materials. J Oral Rehabil. 1999;26(12);936-40.

16- Ruse ND. What is a compomer? J Can Dent Assoc. 1999;65(9):500-4.

17- Sales D, Sae-Lee D, Matsuya S, Ana ID. Short-term fluoride and cations release from polyacid- modified composites in distilled water and an acidic lactate buffer. Biomaterials. 2003;21(10):1687-96.

18- Shaw AJ, Carrick T, McCabe JF. Fluoride release from glass ionomer and compomer restorative materials: 6-month data. J Dent. 1998;26(4):355-6.

19- Veira AR, Souza IPR, Modesto A. Fluoride uptake and release by composite and glass ionomers in a high caries challenge situation. Am J Dent. 1999;12(1):14-8.

20- Weidlich P, Miranda LM, Maltz M, Samuel SMW. Fluoride release and uptake from glass ionomer cements and composite resins. Braz Dent J. 2000;11(2):89-96.

21- Xu X, Burgess JO. Compressive strength, fluoride release and recharge of fluoride-releasing materials. Biomaterials. 2003;24(14):2451-61. 